\title{
ANIMASI PENDIDIKAN UNTUK MENIGKATKAN KARAKTER SISWA SEKOLAH DASAR
}

\author{
Desak Made Agung Ratih Rosmilasari \\ SD Public School Denpasar \\ e-mail: desakagungratih@gmail.com
}

\begin{abstract}
Abstrak
Penelitian ini bertujuan untuk mengetahui pengaruh animasi pendidikan terhadap peningkatan karakter siswa sekolah dasar. Penelitian ini menggunakan desain one group pretest posttest. Penelitian dilakukan di SD Bali Public School dengan jumlah populasi 1 kelas yang sekaligus digunakan sebagai sampel dengan jumlah siswa 20 orang. Untuk mengukur terjadinya peningkatan karakter siswa digunakan instrumen berupa lembar observasi dan pedoman wawancara. Lembar observasi digunakan dalam dua tahap. Tahap pertama dilakukan sebelum diterapkannya animasi pendidikan, sedangkan tahap kedua dilakukan setelah animasi pendidikan diterapkan. Metode wawancara digunakan untuk mengklarifikasi sikap-sikap yang tidak dapat diamati dan diukur ketika menggunakan lembar observasi. Untuk mengetahui perbedaan secara signifikan antara sebelum dan sesudah mendapatkan perlakuan digunakan statistik inferensial berupa uji-t berbantuan SPSS. Hasil penelitian terdapat perbedaan skor karakter yang signifikan antara sebelum dan setelah animasi pendidikan diterapkan dalam pembelajaran. Peningkatan terjadi pada semua sikap yang diteliti yaitu sikap: (1) jujur, (2) disiplin, (3) tanggung jawab, (4) toleransi, dan (5) spiritual.
\end{abstract}

Kata-kata kunci : karakter, animasi pendidikan

\begin{abstract}
This study aims to determine the effect of educational animation on improving the character of elementary school students. This study uses the design of the one group pretest posttest. The study was conducted at SD Bali Public School with a population of 1 class which was simultaneously used as a sample of 20 students. To measure the increase in student character, the instrument was used in the form of an observation sheet and interview guidelines. The observation sheet is used in two stages. The first stage was carried out before the application of educational animation, while the second stage was carried out after educational animation was applied. The interview method is used to clarify attitudes that cannot be observed and measured when using observation sheets. To find out the differences significantly between before and after getting the treatment, inferential statistics were used in the form of SPSS assisted t-test. The results of the study there were significant differences in character scores between before and after educational animation was applied in learning. Increases occur in all attitudes studied, namely attitudes: (1) honest, (2) discipline, (3) responsibility, (4) tolerance, and (5) spiritual.
\end{abstract}

Keywords: character, educational animation 


\section{Pendahuluan}

Karakter adalah watak, tabiat, akhlak, atau kepribadian seseorang yang terbentuk dari hasil internalisasi berbagai kebajikan (virtues) yang diyakini dan digunakan sebagai landasan untuk cara pandang, berpikir, bersikap, dan bertindak. Sejalan dengan visi pembangunan, pendidikan merupakan ujung tombak untuk mengembangkan kemampuan dan watak serta peradaban bangsa. Melalui pendidikan potensi peserta didik dapat dikembangkan agar menjadi manusia yang beriman dan bertaqwa kepada Tuhan yang Maha Esa, berakhlak mulia, sehat, berilmu, cakap, kreatif, mandiri, dan menjadi warga negara yang demokratis serta bertanggung jawab.

Memasuki abad ke-21 persoalan karakter menjadi sorotan tajam masyarakat. Sorotan itu mengenai berbagai aspek kehidupan, yang tertuang dalam berbagai tulisan di media cetak, wawancara, dialog, dan gelar wicara di media elektronik. Mustari (2012) menyatakan ada dua persoalan pembangunan karakter yang sedang dihadapi, yaitu persoalan makro dan persoalan mikro. Persoalan makro: (1) disorientasi dan belum dihayatinya nilai-nilai Pancasila sebagai ideologi bangsa, (2) keterbatasan perangkat kebijakan terpadu nilai Pancasila, (3) bergesernya nilai etika dalam kehidupan berbangsa dan bernegara, (4) memudarnya kesadaran nilai-nilai budaya bangsa, (5) ancaman disintegrasi bangsa, dan (6) melemahnya kemandirian bangsa. Persoalan mikro: (1) tawuran pelajar, (2) penyalahgunaan obat-obat terlarang, (3) pelanggaran disiplin, (4) kurangnya kesadaran akan kebersihan, (5) merosotnya budaya antri, dan lain sebagainya.

Persoalan karakter tidak hanya dialami oleh kalangan remaja, namun ada juga kasuskasus yang terjadi pada anak-anak SD. Akhir-akhir ini tersebar berita yang menunjukkan merosotnya moral yang terjadi di kalangan anak-anak sekolah Dasar. Pada bulan Maret 2016 ada kasus bocah SD dengan bangga memamerkan kebersamaanya dengan sang pacar di dalam kamar dan mengunggahnya ke media sosial (http://www.kompasiana.com). Kasus terbaru pada bulan Juli tahun 2018 ada kasus bocah SD tewas dengan luka sabetan benda tajam (http://news.detik.com). Terjadinya kenakalan dan kekerasan pada anak-anak disinyalir karena maraknya tayangan kekerasan di televisi, game online dan media sosial.

Pendidikan dasar khusus di Sekolah Dasar berkewajiban mengembangkan karakter siswa sebagai lanjutan dari pendidikan karakter dari jenjang pendidikan sebelumnya yaitu Taman kanak-kanak maupun pendidikan di keluarga. Karena proses pengembangan nilainilai karakter merupakan sebuah proses panjang dari awal peserta didik masuk sampai selesai dari suatu satuan pendidikan maka pendidikan karakter perlu digalakkan secara berkelanjutan.

SD Bali Public School (BPS) sebagai salah satu lembaga pendidikan yang ada di Kota Denpasar sangat berkepentingan dalam membangun dan mengembangkan karakter sesuai dengan Tujuan Pendidikan Nasional. Sikap yang diharapkan dimiliki oleh siswa di BPS adalah jujur, bertanggung jawab, percaya diri, toleransi, disiplin, santun, gotong royong, dan spiritual. Untuk dapat mewujudkan hal tersebut tentu dibutuhkan suatu proses yang bermakna dan ketauladan dari warga sekolah.

Berdasarkan penelitian pendahuluan yang dilakukan dan informasi dari beberapa guru menunjukkan bahwa masalah karakter siswa selalu menjadi keprihatinan para guru. Masalah kejujuran, kedisiplinan, tanggung jawab, dan etika siswa selalu menjadi pokok permasalahan. Selaku insan pendidik percaya bahwa pembangunan karakter tidak bisa dibentuk secara instan atau cepat. Membangun karakter memerlukan proses yang panjang dan dibentuk melalui pendidikan dan pembiasaan bukan dihafalkan.

Beberapa upaya dapat dilakukan di SD BPS dalam membangun dan mengembangkan pendidikan karakter siswa, seperti menjadi contoh atau tauladan oleh semua guru dan staf pegawai, menyampaikan nilai-nilai budi pekerti sebelum mulai pembelajaran, dan mengimplementasikan beberapa pendekatan model, strategi, metode dan teknik pembelajaran yang memungkinkan siswa untuk bisa berlatih mengembangkan nilai-nilai 
karakter. Salah satunya yang dapat dilakukan dan dikembangkan oleh guru adalah dengan mengintegrasikan nilai-nilai karakter pada setiap isi perangkat pembelajaran khususnya media pembelajaran. Jenis-jenis media pembelajaran yang dapat dimanfaatkan untuk mengembangkan karakter siswa, yaitu animasi pendidikan.

Fernandes (2002) mengatakan bahwa animasi adalah sebuah proses merekam dan memainkan kembali serangkaian gambar statis atau diam untuk mendapatkan sebuah ilusi gerakan. Definisi ini memiliki makna bahwa gambar diam jika dimanipulasi dan dirangkai hingga menimbulkan pergerakan maka dapat dikatakan sebagai sebuah animasi. Dengan demikian, animasi pendidikan merupakan gambar statis yang menyajikan nilai-nilai pendidikan. Animasi sebagai sebuah media memiliki beberapa keunggulan jika dibandingkan dengan jenis media lainnya. Animasi dapat menghibur siswa, membesarbesarkan (melebih-lebihkan suatu hal), menyederhanakan konsep abstrak (terutama sesuatu yang tidak dapat direkam dengan kamera video), dan mengungkapkan proses yang kompleks. Tujuan penggunaan animasi sebagai media pembelajaran adalah memudahkan dan mengoptimalkan pemahaman peserta didik terhadap konten pembelajaran melalui sajian kata-kata (lisan maupun tulisan) dan gambar (bergerak maupun diam). Animasi memiliki dua kekuatan yang mempengaruhi proses kognitif siswa yaitu visual dan audio. Kedua unsur ini lebih memudahkan peserta didik belajar jika dibandingkan dengan menggunakan kata-kata saja. Dasar pemikiran prinsip ini ialah peserta didik dapat membangun hubungan pengetahuan ketika kata-kata dan gambar disajikan secara bersamaan daripada hanya menggunakan kata-kata saja. Mayer (2003) mencontohkan materi pada buku teks pelajaran yang disajikan dengan kata-kata tercetak dan disertai gambar lebih baik dari pada disajikan dengan kata-kata saja. Keunggulan ini dibuktikan oleh penelitian (Mayer \& Anderson dalam Mayer, 2003) bahwa sajian kata-kata secara lisan dan animasi mampu memudahkan proses belajar peserta didik

Penggunaan animasi tidak terlepas dari hasil-hasil penelitian. Adegoke (2011) meneliti tentang penggunaan animasi, narasi, dan teks sebagai cara untuk menyampaikan pesanpesan pembelajaran. Penggabungan ketiga unsur tersebut ternyata mampu meningkatkan daya ingat siswa dan siswa dapat mengimplementasikan pengetahuannya. Penelitian sejenis juga dilakukan oleh Ogochukwu (2010) yang menunjukkan bahwa presentasi multimedia yang memuat animasi ternyata mampu menarik minat siswa, keterlibatan dalam belajar, membuat pembelajaran menyenangkan, dan siswa mulai menyukai pembelajaran. Hal yang menjadi daya tarik adalah penggunaan audio, visual maupun animasi yang memberikan pilihan belajar visual dan audio dibandingkan audio saja. Hasil-hasil penelitian tersebut merupakan acuan untuk memanfaatkan animasi dalam peningkatan daya ingat siswa dan peningkatan karakter siswa.

Dalam penelitian ini ada empat sikap yang diteliti, yaitu sikap jujur, disiplin, tanggung jawab, toleransi, spiritual, dan percaya diri. Jujur adalah perilaku yang didasarkan pada upaya menjadikan dirinya sebagai orang yang selalu dapat dipercaya dalam perkataan, tindakan, dan pekerjaan, baik terhadap diri sendiri maupun terhadap pihak lain. Disiplin merupakan tindakan yang menunjukkan perilaku tertib dan patuh pada berbagai ketentuan dan peraturan. Tanggung-Jawab merupakan sikap dan perilaku seseorang untuk melaksanakan tugas dan kewajibannya, yang seharusnya dia lakukan, terhadap diri sendiri, masyarakat, lingkungan (alam, sosial dan budaya), negara dan Tuhan Yang Maha Esa. Toleransi adalah sikap dan tindakan yang menghargai perbedaan agama, suku, etnis, pendapat, sikap, dan tindakan orang lain yang berbeda dari dirinya. Spiritual adalah nilai karakter dalam hubungannya dengan Tuhan. la menunjukkan bahwa pikiran, perkataan, dan tindakan seseorang yang diupayakan selalu berdasarkan pada nilai-nilai Ketuhanan dan/atau ajaran agama. Percaya diri adalah nilai karakter yang mampu menunjukkan kemampuan seseorang untuk dapat memahami dan meyakini seluruh potensinya agar dapat dipergunakan dalam menghadapi penyesuaian diri dengan lingkungan hidupnya.

Melalui penerapan animasi pendidikan diharapkan siswa dapat mengetahui nilai-nilai luhur dalam kehidupan sehari-hari khususnya nilai kejujuran, disiplin, tanggung jawab, toleransi, percaya diri, dan spiritual. Selanjutnya nilai tersebut diimplementasikan di mana 
saja dan dengan siapa saja. Sehingga dengan penerapan animasi pendidikan diharapkan karakter siswa bisa lebih berkembang dan meningkat dari sebelumnya. Dengan demikian dapat dirumuskan tujuan dari penelitian ini yaitu untuk mengetahui keefektifan animasi pendidikan dalam meningkatkan karakter siswa sekolah dasar.

\section{Metode}

Penelitian ini merupakan penelitian pra eksperimen dengan rancangan menggunakan subjek yang sama. Penelitian dilakukan di SD Bali Public School dengan menggunakan rancangan penelitian one group pretest posttest design seperti Gambar 3.1.

Tabel 1. Desain One Group Pretest Posttest

\begin{tabular}{|c|c|c|}
\hline Pretest & Variabel Bebas & Posttest \\
\hline 01 & $\mathrm{X}$ & $\mathrm{O} 2$ \\
\hline $\begin{array}{l}\text { Keterangan } \\
\mathrm{O}_{1} \\
X \\
\mathrm{O}_{2}\end{array}$ & $\begin{array}{l}\text { Pengamatan sebelum penerapan media } \\
\text { perlakukan dengan pembelajaran mengg } \\
\text { Pengamatan setelah penerapan media a }\end{array}$ & $\begin{array}{l}\text { re test) } \\
\text { i pendidikan } \\
\text { st test) }\end{array}$ \\
\hline
\end{tabular}

Variabel terikat dalam penelitian ini adalah skor pada masing-masing karakter siswa, yaitu Jujur, disiplin, tanggung jawab, toleransi, spiritual, dan percaya diri. Populasi dalam penelitian ini adalah siswa kelas $2 \mathrm{C}$ yang sekaligus sebagai sampel penelitian yang berjumlah 20 orang. Metode pengumpulan data yang digunakan adalah metode observasi untuk mengamati perkembangan karakter siswa dan metode wawancara untuk mengukur dan mencari data yang tidak dapat diperoleh melalui metode observasi. Instrumen yang digunakan dalam metode tersebut adalah pedoman observasi dan wawancara. Pedoman tersebut berisi panduan pengamatan dan skor yang diberikan pada masing-masing karakter yang memiliki rentangan 1-4. Data yang telah terkumpul selanjutnya dianalisis menggunakan statistik deskriptif. Untuk dapat memberikan makna sekaligus kualifikasi karakter siswa kelas 2C SD Bali Public School yang telah menerapkan kurikulum 2013 digunakan ketetapan sebagai berikut.

Tabel 2. Konversi Tingkat Karakter

\begin{tabular}{cl}
\hline Skor rata-rata persen (M\%) & \\
\hline $90-100$ & Sangat baik \\
$75-89$ & Baik \\
$65-74$ & Cukup baik \\
$55-64$ & Kurang baik \\
$0-54$ & Sangat kurang baik \\
\hline
\end{tabular}

Selanjutnya untuk menguji hipotesis penelitian digunakan metode analisis statistik inferensial yaitu suatu pengolahan data yang dilakukan dengan jalan menerapkan rumusrumus statistik inferensial untuk menguji suatu hipotesis penelitian yang diajukan peneliti, dan kesimpulan ditarik berdasarkan hasil pengujian terhadap hipotesis (Agung, 2012). Statistik inferensial berupa uji-t digunakan menganalisis perbedaan skor pretest dan posttest yang diperoleh saat penelitian. Uji-t dibantu dengan menggunakan perangkat lunak SPSS.

\section{Hasil dan Pembahasan}

Selama penelitian, sikap yang diukur adalah jujur, disiplin, toleransi, percaya diri, dan tanggung jawab. Penelitian dilakukan selama satu bulan dan film animasi diberikan pada 
awal pembelajaran dimulai dan setelah pembelajaran selesai. Implementasi penayangan animasi pendidikan disajikan pada gambar 3 .

Berdasarkan pengamatan sikap jujur siswa menggunakan lembar observasi dapat diketahui perbedaan skor sikap jujur siswa antara sebelum penerapan media animasi pendidikan dan setelah penerapan media animasi pendidikan seperti tersaji pada Tabel 3.

Tabel 3. Rerata Skor Sikap Jujur

\begin{tabular}{|c|c|c|c|c|c|c|c|}
\hline & & Mean & $\mathrm{N}$ & & & $\begin{array}{l}\text { Std. } \\
\text { Mean }\end{array}$ & Error \\
\hline \multirow[t]{2}{*}{ Pair 1} & Pretest & & 84,75 & 20 & 6,584 & & 1,472 \\
\hline & Posttest & & 94,25 & 20 & 7,122 & & 1,593 \\
\hline
\end{tabular}

Berdasarkan Tabel 3 di atas ternyata rerata skor sikap jujur siswa sebelum mendapatkan perlakuan 84,75 (Baik) dan setelah mendapatkan perlakuan 94,25 (Sangat Baik). Ini artinya terjadi peningkatan sikap jujur siswa dilihat dari skor yang diperoleh dari baik menuju sangat baik. Selanjutnya untuk mengetahui signifikansi perbedaan tersebut dianalisis menggunakan uji-t yang tersaji pada Tabel 4.

Tabel 4. Hasil Uji-t Terhadap Skor Sikap Jujur

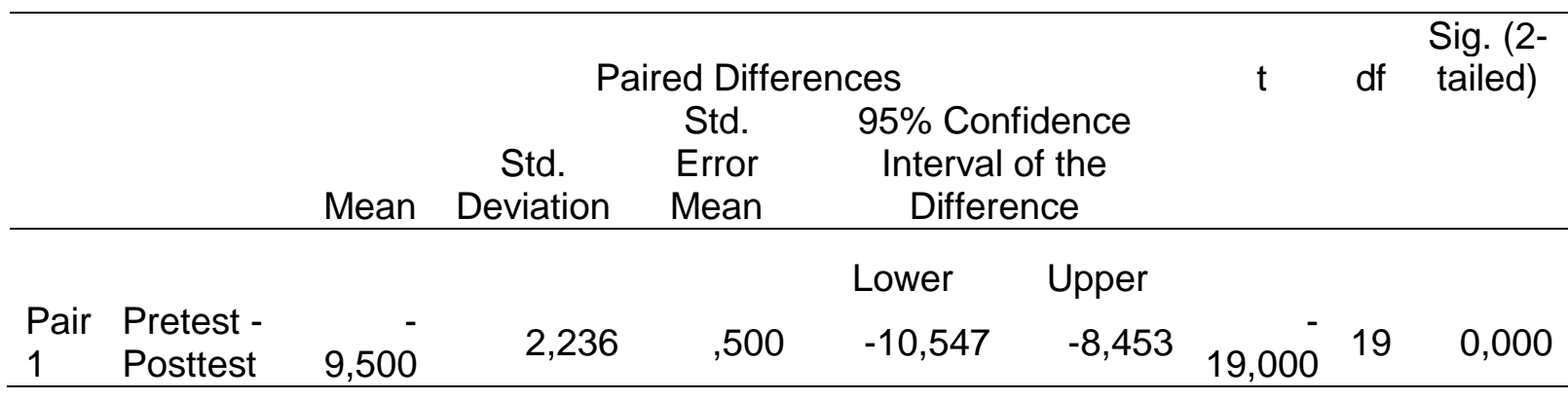

Berdasarkan Tabel 4 di atas pada kolom Sig (2-tailed) diperoleh hasil 0,000 yang kurang dari signifikansi yang ditetapkan yaitu 0,05 . Ini artinya terdapat perbedaan yang signifikan sikap jujur siswa antara sebelum diterapkannya media animasi pendidikan dan setelah diterapkannya media animasi pendidikan.

Pengamatan sikap disiplin siswa menggunakan lembar observasi dapat diketahui perbedaan skor sikap disiplin siswa antara sebelum penerapan media animasi pendidikan dan setelah penerapan media animasi pendidikan seperti tersaji pada Tabel 5.

Tabel 5. Rerata Skor Sikap Disiplin

\begin{tabular}{llrrrr}
\hline & & Mean & N & Std. Deviation & \multicolumn{2}{c}{ Std. Error Mean } \\
\hline Pair 1 & Pretest & 76,88 & 20 & 10,159 & 2,272 \\
& Posttest & 91,88 & 20 & 10,939 & 2,446 \\
\hline
\end{tabular}

Berdasarkan Tabel 5 di atas ternyata rerata skor sikap disiplin siswa sebelum mendapatkan perlakuan 76,88 (Baik) dan setelah mendapatkan perlakuan 91,88 (Sangat Baik). Ini artinya terjadi peningkatan sikap disiplin siswa dilihat dari skor yang diperoleh dari kategori baik menuju sangat baik. Selanjutnya untuk mengetahui signifikansi perbedaan tersebut dianalisis menggunakan uji-t yang tersaji pada Tabel 6 
Tabel 6. Hasil Uji-t Terhadap Skor Sikap Disiplin

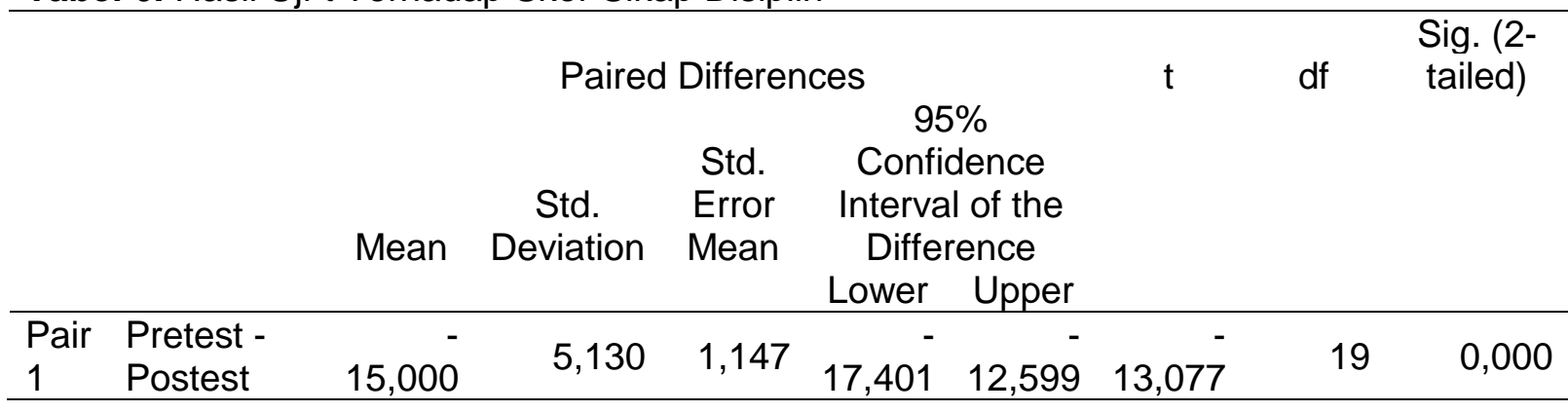

Berdasarkan Tabel 6 di atas pada kolom Sig (2-tailed) diperoleh hasil 0,000 yang kurang dari signifikansi yang ditetapkan yaitu 0,05 . Ini artinya terdapat perbedaan yang signifikan sikap disiplin siswa antara sebelum diterapkannya media animasi pendidikan dan setelah diterapkannya media animasi pendidikan.

Selain sikap disiplin juga diukur sikap tanggung jawab. Berdasarkan pengamatan sikap tanggung jawab siswa menggunakan lembar observasi dapat diketahui perbedaan skor sikap tanggung jawab siswa antara sebelum penerapan media animasi pendidikan dan setelah penerapan media animasi pendidikan seperti tersaji pada Tabel 7.

Tabel 7. Rerata Skor Sikap Tanggung Jawab

\begin{tabular}{|c|c|c|c|c|c|}
\hline \multirow{3}{*}{ Pair 1} & & Mean & $\mathrm{N}$ & Std. Deviation & Std. Error Mean \\
\hline & Pretest & 81,25 & 20 & 7,759 & 1,735 \\
\hline & Postest & 89,50 & 20 & 8,870 & 1,983 \\
\hline
\end{tabular}

Berdasarkan Tabel 7 di atas ternyata rerata skor sikap tanggung jawab siswa sebelum mendapatkan perlakuan 81,25 (Baik) dan setelah mendapatkan perlakuan 89,50 (Sangat Baik). Ini artinya terjadi peningkatan sikap tanggung jawab siswa, dari baik menuju sangat baik. Selanjutnya untuk mengetahui signifikansi perbedaan tersebut dianalisis menggunakan uji-t yang tersaji pada Tabel 8.

Tabel 8. Hasil Uji-t Terhadap Skor Sikap Tanggung Jawab

\begin{tabular}{|c|c|c|c|c|c|c|c|c|c|}
\hline & & & Pairec & Differer & ces & & $t$ & $d f$ & $\begin{array}{l}\text { Sig. (2- } \\
\text { tailed) }\end{array}$ \\
\hline & & Mean & $\begin{array}{c}\text { Std. } \\
\text { Deviation }\end{array}$ & $\begin{array}{l}\text { Std. } \\
\text { Error } \\
\text { Mean }\end{array}$ & $\begin{array}{r}95 \\
\text { Confi } \\
\text { Interva } \\
\text { Differ }\end{array}$ & $\begin{array}{l}\% \\
\text { ence } \\
\text { of the } \\
\text { ence }\end{array}$ & & & \\
\hline & & & & & Lower & Upper & & & \\
\hline $\begin{array}{l}\text { Pair } \\
1\end{array}$ & $\begin{array}{l}\text { Pretest - } \\
\text { Posttest }\end{array}$ & $-8,250$ & 4,064 & 909, & $10,152^{-}$ & $-6,348$ & $-9,079$ & 19 & 0,000 \\
\hline
\end{tabular}

Berdasarkan Tabel 8 di atas pada kolom Sig (2-tailed) diperoleh hasil 0,000 yang kurang dari signifikansi yang ditetapkan yaitu 0,05. Ini artinya terdapat perbedaan yang signifikan sikap tanggung jawab siswa antara sebelum diterapkannya media animasi pendidikan dan setelah diterapkannya media animasi pendidikan.

Pengamatan sikap toleransi siswa menggunakan lembar observasi dapat diketahui perbedaan skor toleransi siswa antara sebelum penerapan media animasi dan setelah penerapan media animasi pendidikan seperti tersaji pada Tabel 9. 
Tabel 9. Rerata Skor Sikap Toleransi

\begin{tabular}{llrrrr}
\hline & & Mean & N & Std. Deviation & \multicolumn{2}{c}{ Std. Error } \\
& & 79,75 & 20 & 5,730 & 1,281 \\
\hline Pair 1 & Pretest & 89,50 & 20 & 5,826 & 1,303 \\
& Posttest & &
\end{tabular}

Berdasarkan Tabel 9 di atas ternyata rerata skor sikap toleransi siswa sebelum mendapatkan perlakuan 79,75 (Baik) dan setelah mendapatkan perlakuan 89,50 (Sangat Baik). Ini artinya terjadi peningkatan sikap toleransi siswa, dari baik menuju sangat baik. Selanjutnya untuk mengetahui signifikansi perbedaan tersebut dianalisis menggunakan uji-t yang tersaji pada Tabel 10.

Tabel 10 Hasil Uji-t Terhadap Skor Sikap Toleransi

\begin{tabular}{|c|c|c|c|c|c|c|c|c|c|}
\hline \multirow[b]{4}{*}{$\begin{array}{l}\text { Pair } \\
1\end{array}$} & \multirow[b]{4}{*}{ Pretest - } & \multicolumn{5}{|c|}{ Paired Differences } & & \multirow[b]{3}{*}{ df } & \multirow{3}{*}{$\begin{array}{l}\text { Sig. (2- } \\
\text { tailed) }\end{array}$} \\
\hline & & \multirow[b]{2}{*}{ Mean } & \multirow{2}{*}{$\begin{array}{c}\text { Std. } \\
\text { Deviation }\end{array}$} & \multirow{2}{*}{$\begin{array}{l}\text { Std. } \\
\text { Error } \\
\text { Mean }\end{array}$} & \multicolumn{2}{|c|}{$\begin{array}{c}95 \% \\
\text { Confidence } \\
\text { Interval of the } \\
\text { Difference }\end{array}$} & \multirow[b]{2}{*}{$\mathrm{t}$} & & \\
\hline & & & & & Lower & Upper & & & \\
\hline & & $-9,750$ & 1,970 & ,441 & 10,672 & $-8,828$ & 22,132 & 19 & 0,000 \\
\hline
\end{tabular}

Berdasarkan Tabel 10 di atas pada kolom Sig (2-tailed) diperoleh hasil 0,000 yang kurang dari signifikansi yang ditetapkan yaitu 0,05. Ini artinya terdapat perbedaan yang signifikan sikap toleransi siswa antara sebelum diterapkannya media animasi pendidikan dan setelah diterapkannya media animasi pendidikan.

Pengamatan sikap spiritual siswa menggunakan lembar observasi dapat diketahui perbedaan skor sikap spiritual siswa antara sebelum penerapan media animasi pendidikan dan setelah penerapan media animasi pendidikan seperti tersaji pada Tabel 11.

Tabel 11. Rerata Skor Sikap Spiritual

\begin{tabular}{rrrrrr}
\hline & & & & \multicolumn{2}{c}{ Std. Error } \\
& & Mean & N & Std. Deviation & Mean \\
\hline Pair 1 & Pretest & 85,75 & 20 & 4,375 &, 978 \\
& Postest & 94,75 & 20 & 5,250 & 1,174 \\
\hline
\end{tabular}

Berdasarkan Tabel $11 \mathrm{di}$ atas ternyata rerata skor sikap spiritual siswa sebelum mendapatkan perlakuan 85,75 (Baik) dan setelah mendapatkan perlakuan 94,75 (Sangat Baik). Ini artinya terjadi peningkatan sikap spiritual siswa dari baik menuju sangat baik. Selanjutnya untuk mengetahui signifikansi perbedaan tersebut dianalisis menggunakan uji-t yang tersaji pada Tabel 12. 
Tabel 12 Hasil Uji-t Terhadap Skor Sikap Spiritual

\begin{tabular}{|c|c|c|c|c|c|c|c|c|c|}
\hline \multirow[b]{4}{*}{$\begin{array}{l}\text { Pair } \\
1\end{array}$} & \multirow[b]{4}{*}{$\begin{array}{l}\text { Pretest - } \\
\text { Postest }\end{array}$} & \multicolumn{5}{|c|}{ Paired Differences } & & & \multirow{3}{*}{$\begin{array}{l}\text { Sig. (2- } \\
\text { tailed) }\end{array}$} \\
\hline & & \multirow[b]{2}{*}{ Mean } & \multirow{2}{*}{$\begin{array}{c}\text { Std. } \\
\text { Deviation }\end{array}$} & \multirow{2}{*}{$\begin{array}{l}\text { Std. } \\
\text { Error } \\
\text { Mean }\end{array}$} & \multicolumn{2}{|c|}{$\begin{array}{c}95 \% \\
\text { Confidence } \\
\text { Interval of the } \\
\text { Difference }\end{array}$} & \multirow[b]{2}{*}{$\mathrm{t}$} & \multirow[b]{2}{*}{ df } & \\
\hline & & & & & Lower & Upper & & & \\
\hline & & $-9,000$ & 2,052 & ,459 & $-9,960$ & $-8,040$ & $19,615^{-}$ & 19 & 0,000 \\
\hline
\end{tabular}

Berdasarkan Tabel 12 di atas pada kolom Sig (2-tailed) diperoleh hasil 0,000 yang kurang dari signifikansi yang ditetapkan yaitu 0,05 . Ini artinya terdapat perbedaan yang signifikan sikap spiritual siswa antara sebelum diterapkannya media animasi pendidikan dan setelah diterapkannya media animasi pendidikan.

Pengamatan sikap percaya diri siswa menggunakan lembar observasi dapat diketahui perbedaan skor sikap percaya diri siswa antara sebelum penerapan media animasi dan setelah penerapan media animasi seperti tersaji pada Tabel 13.

Tabel 13. Rerata Skor Sikap Percaya Diri

\begin{tabular}{llrrrr}
\hline & & & & & \multicolumn{2}{c}{ Std. Error } \\
& & Mean & N & Std. Deviation & \multicolumn{1}{c}{ Mean } \\
\hline Pair 1 & Pretest & 83,00 & 20 & 5,477 & 1,225 \\
& Posttest & 89,00 & 20 & 5,525 & 1,235 \\
\hline
\end{tabular}

Berdasarkan Tabel 13 di atas ternyata rerata skor sikap percaya diri siswa sebelum mendapatkan perlakuan 83,00 (Baik) dan setelah mendapatkan perlakuan 89,00 (Baik). Ini artinya terjadi peningkatan sikap percaya diri siswa, dilihat dari skor yang diperoleh. Selanjutnya untuk mengetahui signifikansi perbedaan tersebut dianalisis menggunakan uji-t yang tersaji pada Tabel 14.

Tabel 14 Hasil Uji-t Terhadap Skor Sikap Percaya Diri

\begin{tabular}{|c|c|c|c|c|c|c|c|c|c|}
\hline & & & Paire & Differer & ces & & $\mathrm{t}$ & $d f$ & $\begin{array}{l}\text { Sig. (2- } \\
\text { tailed) }\end{array}$ \\
\hline & & Mean & $\begin{array}{c}\text { Std. } \\
\text { Deviation }\end{array}$ & $\begin{array}{l}\text { Std. } \\
\text { Error } \\
\text { Mean }\end{array}$ & $\begin{array}{r}95 \\
\text { Confio } \\
\text { Interval } \\
\text { Differ }\end{array}$ & $\begin{array}{l}\% \\
\text { ence } \\
\text { of the } \\
\text { ence }\end{array}$ & & & \\
\hline & & & & & Lower & Upper & & & \\
\hline $\begin{array}{l}\text { Pair } \\
1\end{array}$ & $\begin{array}{l}\text { Pretest - } \\
\text { Postest }\end{array}$ & $-6,000$ & 2,052 & ,459 & $-6,960$ & $-5,040$ & $13,077^{-}$ & 19 & 0,000 \\
\hline
\end{tabular}

Berdasarkan Tabel 15 di atas pada kolom Sig (2-tailed) diperoleh hasil 0,000 yang kurang dari signifikansi yang ditetapkan yaitu 0,05. Ini artinya terdapat perbedaan yang signifikan sikap percaya diri siswa antara sebelum diterapkannya media animasi pendidikan dan setelah diterapkannya media animasi pendidikan.

Berdasarkan hasil penelitian ternyata secara keseluruhan sikap yang diobservasi mengalami peningkatan. Adapun sikap tersebut sikap Jujur, disiplin, tanggung jawab, 
toleransi, spiritual, dan percaya diri. Ada beberapa faktor yang menyebabkan terjadinya peningkatan karakter siswa setelah diterapkannya media animasi pendidikan.

Pertama, media animasi pendidikan memudahkan anak didik memahami dan mengingat nilai-nilai karakter. Seperti diketahui karakter dibentuk melalui pembiasan. Pembiasan bermula dari pengetahuan. Pengetahuan yang baik dan terbiasa dilakukan akan membentuk karakter. Ada anak didik melakukan perbuatan baik karena sudah mengetahui perbuatan baik. Namun ada pula anak didik yang melakukan perbuatan tidak baik karena ia tidak mengetahui apa itu perbuatan baik. Untuk itu, pengetahuan tentang perbuatan baik atau sikap-sikap luhur atau karakter yang berbudi pekerti perlu kembali ditingkatkan. Salah satu caranya dengan menerapkan media audio visual berupa film animasi pendidikan. Media animasi pendidikan diterapkan pada setiap pembelajaran untuk memberikan kepada siswa tentang pemahaman nilai-nilai karakter. Prosedur pemanfaatannya, yaitu dipilih media animasi pendidikan yang mengandung konten karakter dan memiliki kaitan dengan materi atau tema pembelajaran yang sedang berlangsung di SD. Pemutaran animasi pendidikan dilakukan pada kegiatan apersepsi dan kegiatan inti pembelajaran. Pemutaran animasi berdurasi 5-10 menit untuk satu jenis pendidikan karakter. Setelah ditayangkan media animasi ternyata siswa lebih mudah memahami dan mengingat jenis-jenis sikap yang baik seperti sikap disiplin dan tanggung jawab. Hasil penelitian ini didukung oleh penelitian yang dilakukan Mayer \& Anderson (dalam Mayer, 2003) yang menemukan bahwa penggunaan media audio visual mampu meningkatkan pemahaman dan daya ingat siswa terhadap materi. Pada tahap ini anak didik baru memahami jenis-jenis karakter yang baik. Selanjutnya pengetahuan tersebut perlu diimplementasikan dalam lingkungan sekolah maupun di luar lingkungan sekolah. Untuk mengetahui bahwa siswa sudah mengimplementasikan pengetahuan tersebut, diamati dengan metode observasi. Selain itu, untuk menguatkan hasil observasi, dilakukan pula kegiatan wawancara dengan siswa dalam suasana nyaman dan kekeluargaan. Ini dilakukan agar tidak membuat siswa merasa tertekan terhadap pertanyaan-pertanyaan yang diberikan oleh guru (peneliti).

Kedua, pemutaran media animasi yang berulang-ulang dengan topik yang berbedabeda ternyata mendorong anak didik untuk meniru perilaku tokoh-tokoh baik dalam film animasi pendidikan. Artinya dengan pembiasan pemberian nilai-nilai membuat karakter baik siswa mulai terbentuk. Berdasarkan hasil observasi ternyata setelah sekian hari pemutaran media pendidikan ternyata ada beberapa siswa menunjukkan sikap yang baik. Ada siswa yang sebelumnya tidak peduli dengan kebersihan, seperti kebersihan kolong meja, setelah menyajikan animasi pendidikan yang menyajikan tentang peduli lingkungan, ternyata ia meniru perilaku tersebut. Kebiasaan tersebut tidak hanya dilakukan sekali bahkan sudah lebih dari tiga kali. Ada juga siswa yang mengalami peningkatan sikap tanggung jawab. Sebelumnya ia tidak pernah tuntas mengerjakan tugas yang diberikan guru, namun setelah menonton animasi tentang tanggung jawab dan mengetahui akibat negatif dari melalaikan tanggung jawab, ia mulai mengerjakan tugas-tugas secara tuntas. Ada juga siswa yang kurang disiplin menjadi lebih disiplin setelah menonton film animasi. Setelah menonton film, anak tersebut mulai menyadari akan pentingnya sikap disiplin. Begitu juga dengan nilai-nilai kejujuran juga meningkat ketika siswa mengetahui dampak negatif jika seseorang suka berbohong. Nilai kejujuran meningkat setelah siswa menyimak film animasi pendidikan. Dalam film tersebut disajikan akibat seseorang yang suka berbohong atau tidak jujur. Setelah menyimak beberapa kali pemutaran animasi ternyata siswa takut melakukan tindakan berbohong yang dapat diketahui melalui tugas rumah yang dikerjakan sendiri (tidak nyontek ke teman), penyampaian alasan tidak masuk sekolah sesuai fakta, mengungkapkan fakta sesungguhanya jika ada teman siswa yang kehilangan alat tulis. Temuan penelitian tersebut mengindikasikan bahwa dengan pembiasan pemberian berupa nilai-nilai membuat siswa terpicu untuk menunjukkan perilaku yang baik pula. Ini ibaratnya orang tua yang selalu memberikan wejangan kepada anaknya agar anaknya selalu berprilaku yang baik. Dalai Lama mengatakan bahwa karakter seseorang dimulai dari caranya berpikir. Untuk itu cara berpikir anak perlu diarahkan dan perlu pembiasan untuk selalu berpikir tentang hal-hal yang baik. Karena dengan berpikir yang baik siswa akan berkata yang baik. Dengan berkata 
yang baik ia akan membentuk perbuatan yang baik. Perbuatan baik dan sering dilakukan akan membentuk kebiasaan. Kebiasaan yang baik akan membentuk karakter. Dengan demikian animasi pendidikan turut memberikan kontribusi terhadap cara pandang dan berpikir anak tentang sikap-sikap yang baik. Sehingga nilai tersebut dapat terbangun dengan kokoh dalam pikiran siswa dan menuntun pembentukan karakter baik anak untuk saat ini maupun kedepannya.

\section{Simpulan dan Saran}

Disimpulkan bahwa terjadi peningkatan karakter siswa menjadi lebih baik setelah diterapkannya film animasi pendidikan. Hal tersebut terjadi seiring dengan pemutaran film animasi yang dilakukan secara continue sehingga apa yang dilihat dan didengar oleh siswa mampu diingat dan menimbulkan kesadaran dari dalam dirinya sendiri untuk melakukannya atau menerapkannya. Untuk itu, disarankan kepada guru agar dalam melaksanakan pembelajaran dapat meluangkan waktunya beberapa menit untuk menyampaikan nilai - nilai karakter yang baik.

\section{Daftar Pustaka}

Adegoke, B. A. 2011. Effect of multimedia instruction on senior secondary school students' achievement in physics. European Journal of Educational Studies. 3(3). 537-550. Tersedia pada http://www.ozelacademy.com.

Agung, A. A. 2012. Metodologi Penelitian Pendidikan. Singaraja: Undiksha.

Balazinski, M. \& Przybylo, A. (2005). Teaching manufacturing processes using computer animation, Journal of Manufacturing Sistem, 2005; 24, 3. ProQuest pg.237 Diakses dari Error! Hyperlink reference not valid.

Dian, Lo Priscilla. 2016. Miris, bocah ini bangga foto "selfie" setelah tidur bersama sang pacar. tersedia pada: http://www.kompasiana.com).

Fernandes, Ibiz. 2002. Animation \& Cartooning: A creative Guide. Osborn, California.

Hakim Ghani. 2018. Bocah kelas 6 SD di garut tewas berkelahi dengan teman sekelas. Tersedia pada: http://news.detik.com)

Mayer, R. E. 2003. The promise of multimedia learning: Using the same instructional design methods across different media. Learning and Instruction. 13. 125-139. Tersedia pada http://sam.arts.unsw.edu.au/ media/File/MayerMediaMethod03.pdf.

Mustari, Mohamad. 2011. Nilai karakter: Refleksi untuk pendidikan karakter. Yogyakarta: LaksBang Pressindo.

Ogochukwu, N. V. 2010. Enhancing students interest in mathematics via multimedia presentation. African Journal of Mathematics and Computer Science Research. 3(7). 107-113. Tersedia pada http://www.academicjournals.org/ajmcsr/PDF/pdf2010/Jul/ Ogochukwu.pdf. 